\title{
Problémy literární vědy dnes
}

Ivo Pospíšil (Brno)

Dne 8. 12. 2017 se na Ústavu slavistiky Filozofické fakulty Masarykovy univerzity v Brně konalo malé kolokvium Literárněvědné společnosti ČR pod názvem Problémy literárni vědy dnes.

Jednání zahájil předseda LVS a autor této zprávy a uvedl první referáty. Libor Pavera (Praha, Bielsko-Biała) v prŕíspěvku Marginálni poznámky jako typ opožděné kritiky zkoumal kritické glosy v knihách, které četli a studovali významní badatelé jako pramen poznání jejich metodologie a konkrétních názorů, vyjadřovaných často jadrnou formou. Jana Kostincová (Hradec Králové) se zabývala poezií v kontextu nových technologií (Poezie síti. Ruský básnický experiment v kontextu nových médii a jeho teoretická reflexe), Giuseppe Maiello (Praha) zkoumal Psané texty v obdobi mobilnich operačnich systémů, Alexej Mikulášek se zabýval stereotypy v literatuře a médiích (Stereotypy v literatuře: mezi literárni vědou a teorii médii), Jaroslav Sommer ukázal na př́stupy literární vědy $\mathrm{k}$ tzv. queer literatuře (Literárni věda a queer), Lenka
Paučová ukázala F. M. Dostojevského jako literárního kritika (Spisovatel a kritik: prístup F. M. Dostojevského $k$ hodnoceni literárnich dèl na základě kritických stati v Deniku spisovatele), Josef Šaur demonstroval zvláštnosti české recepce současné ruské literatury (Paradoxy české recepce současné ruské literatury. Gluchouskij, Rubina, Vodolazkin, Silajev), Ivo Pospíšil se ve svém příspěvku Politická a akademická objednávka v literárni vědě a dvě témata: postsekularismus a ekfráze zabýval dvěma frekventovanými tématy literární vědy.

$\mathrm{V}$ diskusi byla zdůrazněna dnešní nová tvář literární vědy, byl konstatován nezdravý stav literární a literárněvědné komunikace, její uzavřenost a izolovanost diskurzních skupin, stejně jako nezbytí nově pojímat literární proces i v souvislosti s novými technologiemi a zkoumat meziliterární dialog bez ostrakizací a s tolerancí. Př́íspěvky a diskuse z malého kolokvia budou publikovány v novém svazku Kontexty literárni védy v roce 2018.

\section{prof. PhDr. Ivo Pospíšil, DrSc.}

Ústav slavistiky

Filozofická fakulta, Masarykova univerzita

Arna Nováka 1, 60200 Brno, Česká republika

ivo.pospisil@phil.muni.cz 